Postgraduate Bosowa University Publishing (PBUP)
Indonesian Journal of Business and Management
https://postgraduate.universitasbosowa.ac.id/index.php/jbm

\title{
PENGARUH STRES KERJA, ORGANIZATIONAL CITIZENSHIP BEHAVIOR DAN KOMITMEN ORGANISASI TERHADAP KINERJA KARYAWAN PT JAPFA COMFEED INDONESIA TbK. UNIT CORN DRYER SIDRAP
}

\author{
The Effect of Work Stress, Organizational Citizenship Behaviors and Organizational Commitments on \\ the Employee Performance in PT Japfa Comfeed Indonesia Tbk. Unit Corn Dryer Sidrap
}

\author{
Putri Sari Dewi Anjani Sutarjo', Cahyono ${ }^{2}$, Haeruddin Saleh ${ }^{3}$ \\ ${ }^{1}$ Magister Manajemen Universitas Bosowa Makassar \\ ${ }^{2}$ Program Studi Manajemen Program Pascasarjana Universitas Bosowa
}

Email: putrisaridewi163@yahoo.co.id

Diterima: 12 Februari /Disetujui: 05 Juni 2020

\begin{abstract}
ABSTRAK
Penelitian ini bertujuan untuk menganalisis pengaruh stress kerja terhadap kinerja karyawan, pengaruh organizational citizenship behavior, terhadap kinerja karyawan, pengaruh komitmen organisasi terhadap kinerja karyawan dan pengaruh stress kerja, organizational citizenship behavior, dan komitmen organisasi terhadap kinerja karyawan PT Japfa Comfeed Indonesia Tbk. Unit Corn Drier Sidrap. Desain penelitian ini menggunakan metode penelitian kuantitatif dengan menggunakan metode survey. Jumlah sampel dalam penelitian ini 83 orang. Penelitian ini menggunakan teknik analisis kuantitatif yang dianalisis dengan bantuan software SPSS 25. Hasil penelitian menunjukkan bahwa stress kerja berpengaruh negatif dan tidak signifikan terhadap kinerja karyawan PT Japfa Comfeed Indonesia Tbk. Unit Corn Drier Sidrap. Hal ini dapat dilihat nilai koefeisien stres kerja sebesar -0,022 dengan tingkat signifikan 0,330. Organizational Citizenship Behavior berpengaruh positif dan signifikan terhadap kinerja karyawan PT Japfa Comfeed Indonesia Tbk. Unit Corn Drier Sidrap. Hal ini dapat dilihat nilai koefeisien Organizational Citizenship Behavior sebesar 0,186 dengan tingkat signifikan 0,000. Komitmen organisasi berpengaruh positif dan signifikan terhadap kinerja karyawan PT Japfa Comfeed Indonesia Tbk. Unit Corn Drier Sidrap. Hal ini dapat dilihat nilai koefeisien komitmen organisasi sebesar 0,801 dengan tingkat signifikan 0,000. Stres Kerja, Organizational Citizenship Behavior dan komitmen organisasi berpengaruh positif dan signifikan terhadap kinerja karyawan PT Japfa Comfeed Indonesia. Hal ini dapat dilihat dari hasil perhitungan secara simultan nilai $\mathrm{F}$ hitung sebesar 297,112 dengan tingkat signifikan 0,000.
\end{abstract}

Kata Kunci: Stres Kerja, Organizational Citizenship Behavior dan Komitmen Organisasi Kinerja Karyawan

\begin{abstract}
This study aims to examine and analyze 1. The effect of work stress on employee performance; 2. The effect of organizational citizenship behavior on employee performance; 3. The influence of organizational commitment to employee performance; 4. The influence of work stress, organizational citizenship behavior, and organizational commitment on the employee performance in PT Japfa Comfeed Indonesia Tbk. Unit Corn Drier Sidrap. The research design used is a quantitative research approach using survey method. The number of samples in this study was 83 people. This research uses quantitative analysis techniques that are analyzed with the help of SPSS 25 software. The conclusions from the results of this study are 1. Work Stress has a negative and not significant effect on the performance of the employees of PT JapfaComfeed Indonesia Tbk. Unit Corn Drier Sidrap. It can be seen that the coefficient of work stress is -0.022 with a significant level of 0.330; 2. Organizational Citizenship Behavior has a positive and significant effect on the performance of the employees of PT JapfaComfeed Indonesia Tbk. Unit Corn Drier Sidrap. This can be seen from the Organizational Citizenship Behavior coefficient value of 0.186 with a significant level of 0,000; 3. Organizational commitment has a positive and significant effect on the performance of the employees of PT JapfaComfeed Indonesia Tbk. Unit Corn Drier Sidrap. It can be seen that the coefficient value of organizational commitment is 0.801 with a significant level of $0.000 ; 4$.
\end{abstract}


Job Structure, Organizational Citizenship Behavior and Organizational Commitment have a positive and significant effect on the Employee Performance of PT JapfaComfeed Indonesia. This can be seen from the results of the simultaneous calculation of the calculated $F$ value of 297,112 with a significant level of 0,000.

Keywords: Job Stress, Organizational Citizenship Behavior and Organizational Commitment of Employee Performance

\section{PENDAHULUAN}

Jagung adalah salah satu bahan komoditi penting yang digunakan dalam proses produksi pakan ternak. Penggunaan jagung untuk produksi pakan ternak dari tahun 2018 ketahun 2019 mengalami peningkatan dari 10,3 juta ton menjadi 11,82 ton.Hal ini membuktikan kenaikan akan pengggunaan jagung sebagai bahan baku pakan ternak sangatlah tinggi yang disebabkan oleh tingginya permintaan pakan ternak untuk peternakan. Hal ini dipengaruhi oleh tingginya permintaaan akan kebutuhan konsumsi daging yang meningkatkan dilhat dari permintaan konsumen yang semakin tinggi dengan produk daging.

Hal yang perlu diperhatikan dalam pengembangan sumber daya manusia dalam mengelolah produksi jagung oven yaitu memilih supplier yang memiliki kualitas jagung yang terbaik, dengan cara memilah jagung yang berkualitas sesuai dengan ketentuan perusahaan dan dapat menggunakan mesin pengeringan jagung dari pengaturan suhu ovennya sampai kapasitas yang dapat diproduksi mesin pengering jagung. sehingga mampu memproduksi jagung oven yang berkualitas tinggi.

PT Japfa Comfeed Indonesia Tbk. Unit Corn Drier Sidrap lebih fokus dalam usaha produksi kualitas jagung oven sebagai bahan pokok pembuatan pakan ternak. Memiliki pelanggan JCI Tangerang, JCI Cikande, JCI Sidoarjo, JCI Gedangan, JCI Bajarmasin, JCI Makassar, CD Gowa dan Peternakan. Serta membantu menyerap tenaga kerja disekitar wilayah PT Japfa Comfeed Indonesia Tbk. Unit Corn Drier Sidrap kesejateraan petani dengan cara menyerap hasil jagung petani sesuai mutu perusahaan untuk produksi jagung kualitas oven.

Mangkunegara (2013) mendefinisikan "kinerja karyawan sebagai prestasi kerja atau hasil kerja baik kualitas maupun kuantitas yang dicapai karyawan persatuan periode dalam melaksanakan tugas kerjanya sesuai dengan tanggung jawab yang diberikan kepadanya. Permasalahan penurunan kinerja karyawan dilihat dari hasil wawancara sebagai berikut penggunaan waktu yang kurang optimal. Kesungguhan karyawan dalam pelaksanaan pekerjaan tergolong rendah, kerja sama antar karyawan belum optimal. Karyawan tidak dapat menyelesaikan pekerjaan sesuai dengan waktu yang ditentukan. Penurunan tanggung jawab kerja disebabkan oleh bertambahnya beban kerja sehingga terjadi ketidakseimbangan antara beban kerja dan sumber daya manusia. Faktor yang menurunkan kinerja karyawan dalam penelitian ini adalah stres kerja organizatinal citizenship behavior dan komitmen organisasi (Pigome et al. 2019).

Faktor pertama yang mempengaruhi kinerja karyawan yaitu stres kerja. Stres Kerja merupakan kondisi dinamis seorang individu dihadapkan dalam kesempatan, keterbatasan, atau tuntutan sesuai dengan harapan dan hasil yang ingin dicapai dalam kondisi penting dan tidak menentu. Berdasarkan hasil wawancara dapat diketahui stres kerja dimana dapat dilihat dari beban kerja yang diberikan tidak sesuai dengan pekerjaan karyawan. Tingkat stres yang dialami karyawan berbeda-beda tergantung pada masing-masing level (jabatan) sesuai dengan beban kerja yang diterima. Tekanan dari atasan dan klien juga menambah beban pekerjaan karyawan tidak berimbangnya antara beban kerja dan imbalan yang diterima juga menjadi indikasi munculnya stres kerja. Sunyoto (2013) menyatakan bahwa pada tingkat stres yang rendah kinerja karyawan rendah. Wartono Tri (2017) yang menunjukkan bahwa stres kerja berpengaruh positif dan signifikan terhadap kinerja karyawan.

Faktor kedua yang mempengaruhi kinerja karyawan yaitu Organzational Citizenship Behavior. Perilaku kewargaan organisasional adalah dasar kepribadian yang direfleksikan melalui perilaku kooperatif, suka menolong, perhatian dan bersungguh-sungguh, serta dasar sikap yang direfleksikan melalui rasa ingin membalas tindakan organisasi (Luthans, 2006). Berdasarkan hasil wawancara masih terdapat beberapa karyawan yang tidak memiliki sifat Organzational Citizenship Behavior karena masih ada beberapa karyawan yang tidak mau menolong karyawan yang sekiranya mengalami kesulitan. Hal ini terlihat dari perilaku ketika karyawan lain minta bantuan untuk membantu, mereka masih terkesan tidak mau atau menunda dengan melakukan aktivitas lain. Keadaan ini juga terjadi ketika ada suatu tugas yang harus diselesaikan ternyata karyawan tersebut tetap pulang tepat waktu karena suatu alasan tertentu seperti misalnya alasan keperluan keluarga padahal tugas belum selesai.

Disamping itu, masih terlihat adanya sebagian karyawan yang membuat kelompok kecil dalam lingkungan kerja yang semakin membuat jarak antar individu secara keseluruhan, sehingga perilaku saling membantu secara sukarela hanya terjadi pada kelompok mereka sendiri. Gibson, et al (2011) lebih lanjut memperinci bahwa perilaku organisasional bisa memaksimalkan efisiensi dan produktivitas karyawan maupun organisasi yang pada akhirnya memberi kontribusi pada fungsi efektif dari suatu organisasi. Penelitian Linda Kartini Ticoalu (2013) Organizational Citizenship Behavior $(O C B)$, berpengaruh signifikan terhadap kinerja karyawa pada PT. Bank Tabungan Pensiunan Nasional (BTPN) Cabang Utama Manado.

Faktor ketiga yang mempengaruhi kinerja karyawan adalah komitmen organisasi.Komitmen organisasi merupakan suatu keadaan ketika seorang karyawan berpihak kepada suatu organisasi tertentu dengan tujuan untuk mempertahankan keanggotaan pada 
organisasi tersebut Robbins dan Judge (2008). Luthans, (2006) bahwa individu yang berkomitmen organisasi tinggi akan membuka kesempatan terjadinya interaksi dengan individu yang lain selama bekerja bersama dalam kegiatan organisasi.

Berdasarkan hasil wawancara komitmen organisasi diketahui beberapa karyawannya yang mulai suka terlambat masuk kerja, tingkat absen karyawan rendah, Terlambatnya upah yang diberikan dapat menurunkan loyalitas karyawan. Banyaknya karyawan yang tidak disiplin dapat mempengaruhi kerja tim dalam menyelesaikan produksi produk permintaan customer. Robbins dan Judge (2008), komitmen sebagai suatu keadaan dimana seorang individu memihak organisasi serta tujuan-tujuan dan keinginan untuk mempertahankan keanggotaan dalam organisasi Peneliti Martiyani Pristiwati (2018) mengemukakan bahwa Berdasarkan hasil penelitian diperoleh bahwa Komitmen Organisasi secara parsial berpengaruh signifikan positif terhadap kinerja karyawan.

\section{METODE PENELITIAN}

\subsection{Jenis Penelitian}

Jenis Penelitian ini mengunakan penelitian survei. Menurut Sugiyono (2015) penelitian survei adalah metode penelitian kuantitatif yang digunakan untuk mendapatkan data yang terjadi pada masa lampau atau saat ini, tentang keyakinan, pendapat, karakteristik, perilaku, hubungan variabel dan untuk menguji beberapa hipotesis tentang variabel sosiologis maupun psikologis dari sampel yang diambil dari populasi tertentu.

\subsection{Populasi dan Sampel}

Populasi Penelitian ini adalah karyawan pada PT Japfa Comfeed Indonesia Tbk. Unit Corn Drier Sidrap Sebanyak 104 orang yang terbagi dari beberapa departemen Kepala Operasional, Purchasing/sales, Financial Dan Accounting, HRD dan General Affairs, Plant,Quality control dan Outcorsing. Penelitian ini mengambil sampel sebesar 83 berdasarkan hasil rumus sloving.

\subsection{Teknik Pengambilan Sampel}

Teknik pengambilan sampel penelitian ini menggunakan teknik Purposive Sampling. Teknik Purpose Sampling merupakan teknik untuk menentukan sampel penelitian dengan beberapa pertimbangan tertentu Sugiyono (2015).

\subsection{Teknik Pengumpulan Data}

Metode yang digunakan pengumpulan data kueisoner, wawancara, observasi dan studi pustaka.

\subsection{Variabel Penelitian}

Variabel dalam penelitian ini variabel bebeas terdiri dari Stres Kerja, Organizational Citizenship Behavior dan Komitmen Organisasi. Variabel Terikat terdiri dari Kinerja Karyawan.

\section{HASIL DAN PEMBAHASAN}

\subsection{Deskripsi Karakterisik Responden}

Jumlah responden sebanyak 83 diketahui jumlah responden perempuan sebanyak 40 orang dengan presentase $48 \%$ dan responden laki-laki memiliki responden sebanyak 43 orang dengan presentase 52\%. Responden usia $\leq 20$ tahun sebanyak 10 orang dengan presentase $12 \%$ dan responden 21 - 28 tahun memiliki responden sebanyak 21 orang dengan presentase $25 \%$, responden usia 29-36 tahun sebanyak 25 orang dengan persentase $30 \%$, responden usia 37-44 tahun sebanyak 18 orang dengan presentase $22 \%$ dan responden usia $\geq 45$ tahun sebanyak 9 orang dengan presentase $11 \%$.

Tingkat Pendidikan responden pendidikan SMA sebanyak 44 orang dengan presentase 53\%, responden pendidikan Diploma sebanyak 10 orang dengan presentase $12 \%$, reponden SI sebanyak 26 orang dengan presentase $31 \%$ dan responden S2 sebanyak 3 orang dengan presentase $4 \%$. Responden Berdasarkan Jabatan responden kepala Operasonal sebanyak 1 orang dengan presentase $1 \%$, responden kepala departemen sebanyak 5 orang dengan presentase 6\%, responden Staf Pica dan Sales sebanyak 2 orang dengan presentase,responden Staf Financial Dan Accounting (F \& A) sebanyak 3 orang dengan presentase $4 \%$, responden Staf HRD dan GDA sebanyak 9 orang dengan presentase $11 \%$. responden. Staf Quality Control sebanyak 5 orang dengan presentase 6\% responden staf plant sebanyak 14 orang dengan presentase $17 \%$ dan responden Outsorcing memiliki responden sebanyak 44 orang dengan presentase $53 \%$. responden lama bekerja 2-6 tahun sebanyak $32 \%$ orang dengan presentase 39\% dan responden lama bekerja 7-11 tahun memiliki responden sebanyak 51 orang dengan presentase $61 \%$.

\subsection{Analisis Uji Instrumen Penelitian}

\section{$1 \quad$ Uji Validitas}

Uji validitas digunakan untuk menguji sejauh mana ketepatan alat pengukur dapat mengungkapkan konsep gejala/kejadian yang diukur. Teknik pengujiannya menggunakan korelasi product moment dan pearson dengan menggunakan tingkat signifikan $0,05 \%$, Item kuesioner dinyatakan valid apabila nilai $r$ hitung $>r$ tabel ( $n-2)$, dimana $r$ tabel sebesar 0,183 . Pengujian validitas selengkapnya dapat dilihat pada tabel berikut ini.

Tabel 1 Uji Validitas

\begin{tabular}{lcccc}
\hline Variabel & Kode & (r-hitung $)$ & $\begin{array}{c}(\mathrm{r} \text { tabel }) \\
(\mathrm{n}=83 ; \alpha=0,05)\end{array}$ & Ket \\
\hline \multirow{5}{*}{ Stres Kerja } & SK1 & 0,499 & 0,183 & Valid \\
& SK2 & 0,341 & 0,183 & Valid \\
& SK3 & 0,427 & 0,183 & Valid \\
& SK4 & 0,492 & 0,183 & Valid \\
& SK5 & 0,491 & 0,183 & Valid \\
& SK6 & 0,300 & 0,183 & Valid \\
& SK7 & 0,533 & 0,183 & Valid \\
& SK8 & 0,459 & 0,183 & Valid \\
& SK9 & 0,395 & 0,183 & Valid \\
& SK10 & 0,558 & 0,183 & Valid \\
& SK11 & 0,504 & 0,183 & Valid \\
\hline
\end{tabular}




\begin{tabular}{|c|c|c|c|c|}
\hline & SK12 & 0,560 & 0,183 & Valid \\
\hline \multirow{13}{*}{$\begin{array}{l}\text { Organizatio } \\
\text { nal } \\
\text { Citizenship } \\
\text { Behavior }\end{array}$} & OCB1 & 0,361 & 0,183 & Valid \\
\hline & OCB2 & 0,520 & 0,183 & Valid \\
\hline & OCB3 & 0,619 & 0,183 & Valid \\
\hline & OCB4 & 0,545 & 0,183 & Valid \\
\hline & OCB5 & 0,629 & 0,183 & Valid \\
\hline & OCB6 & 0,664 & 0,183 & Valid \\
\hline & OCB7 & 0,587 & 0,183 & Valid \\
\hline & OCB8 & 0,564 & 0,183 & Valid \\
\hline & OCB9 & 0,428 & 0,183 & Valid \\
\hline & OCB 10 & 0,413 & 0,183 & Valid \\
\hline & OCB11 & 0,292 & 0,183 & Valid \\
\hline & OCB12 & 0,168 & 0,183 & Valid \\
\hline & OCB13 & 0,265 & 0,183 & Valid \\
\hline \multirow{12}{*}{$\begin{array}{l}\text { Komitmen } \\
\text { Organisasi }\end{array}$} & KO1 & 0,444 & 0,183 & Valid \\
\hline & $\mathrm{KO} 2$ & 0,530 & 0,183 & Valid \\
\hline & $\mathrm{KO} 3$ & 0,504 & 0,183 & Valid \\
\hline & $\mathrm{KO} 4$ & 0,383 & 0,183 & Valid \\
\hline & KO5 & 0,360 & 0,183 & Valid \\
\hline & KO6 & 0,449 & 0,183 & Valid \\
\hline & KO7 & 0,510 & 0,183 & Valid \\
\hline & $\mathrm{KO} 8$ & 0,583 & 0,183 & Valid \\
\hline & KO9 & 0,681 & 0,183 & Valid \\
\hline & KO10 & 0,476 & 0,183 & Valid \\
\hline & KO11 & 0,681 & 0,183 & Valid \\
\hline & KO12 & 0,476 & 0,183 & Valid \\
\hline \multirow{12}{*}{$\begin{array}{l}\text { Kinerja } \\
\text { Karyawan }\end{array}$} & KK1 & 0,572 & 0,183 & Valid \\
\hline & KK2 & 0,454 & 0,183 & Valid \\
\hline & KK3 & 0,475 & 0,183 & Valid \\
\hline & KK4 & 0,519 & 0,183 & Valid \\
\hline & KK5 & 0,592 & 0,183 & Valid \\
\hline & KK6 & 0,490 & 0,183 & Valid \\
\hline & KK7 & 0,467 & 0,183 & Valid \\
\hline & KK8 & 0,409 & 0,183 & Valid \\
\hline & KK9 & 0,454 & 0,183 & Valid \\
\hline & KK10 & 0,546 & 0,183 & Valid \\
\hline & KK11 & 0,526 & 0,183 & Valid \\
\hline & KK12 & 0,321 & 0,183 & Valid \\
\hline
\end{tabular}

Tabel diatas menunjukkan bahwa hasil uji reliabilitas variabel penelitian menunjukkan penelitian mempunyai koefisien keadaan/ alpha lebih besar dari 0,6 sehingga semua instrumen dinyatakan reliabel, dengan demikian data penelitian tersebut bersifat valid dan layak digunakan untuk pengujian hipotesis.

3. Uji Asumsi Klasik

Uji prasyarat analisis dalam penelitian ini terdiri dari uji normalitas, uji linieritas, multikolinieritas dan uji heteroskedastisitas.

\section{a. Uji Normalitas}

Uji Normalitas bertujuan untuk menguji apakah dalam model regresi, variabel pengganggu atau residual memiliki distribusi normal. Jika asumsi ini dilanggar maka uji statistik menjadi tidak valid. Model regresi yang baik adalah model yang berdistribusi normal. Ghozali (2013).

Hasil penelitian dikategorikan berdistribusi normal jika nilai signifikansi berada diatas 0,50.

Tabel 3 Uji Normalitas

\begin{tabular}{|c|c|c|c|c|c|}
\hline \multicolumn{6}{|c|}{ One Sample Kolmogorov Smirnov Test } \\
\hline & & $\begin{array}{l}\text { Stress } \\
\text { Kerja }\end{array}$ & $\begin{array}{c}\text { Organizational } \\
\text { Citizenzship } \\
\text { Behavior }\end{array}$ & $\begin{array}{c}\text { Komitm } \\
\text { en } \\
\text { Organisa } \\
\text { si } \\
\end{array}$ & $\begin{array}{c}\text { Kinerja } \\
\text { Karyawa } \\
\mathrm{n}\end{array}$ \\
\hline $\mathrm{N}$ & & 83 & 83 & 83 & 83 \\
\hline \multirow{2}{*}{$\begin{array}{l}\text { Normal } \\
\text { Parameters }{ }^{\mathrm{a}, \mathrm{b}}\end{array}$} & Mean & 1,64 & 4,51 & 4,49 & 4,48 \\
\hline & $\begin{array}{l}\text { Std. } \\
\text { Deviation }\end{array}$ & 0,38 & 0,25 & 0,26 &,- 25 \\
\hline \multirow{3}{*}{$\begin{array}{l}\text { Most Extreme } \\
\text { Differences }\end{array}$} & Absolute & , 101 & , 106 & , 108 & , 129 \\
\hline & Positive & 101 &, 106 & 108 &, 129 \\
\hline & Negative &,- 073 &,- 101 &,- 081 &,- 094 \\
\hline \multicolumn{2}{|c|}{ Test Statistic } &, 101 &, 106 &, 108 &, 129 \\
\hline \multicolumn{2}{|c|}{ Asymp. Sig. (2-tailed) } &, $063^{\mathrm{c}}$ &, $061^{\mathrm{c}}$ & $078^{\mathrm{c}}$ &, $082^{\mathrm{c}}$ \\
\hline
\end{tabular}

Berdasarkan Tabel 3 diatas dapat dinyatakan bahwa nilai signifikansi hasil pengujian masing-masing variabel independen dan dependen telah berada di atas 0,05 . Sehingga dapat disimpulkan bahwa data yang telah dikumpulkan berdistribusi normal atau diambil dari populasi normal.

\section{b. Uji Linieritas}

Duwi Priyatno (2016) menyatakan uji linearitas merupakan uji prasyarat yang biasanya dilakukan jika akan melakukan analisis korelasi pearson atau regresi linear. Uji ini bertujuan untuk mengetahui apakah dua variabel secara signifikan mempunyai hubungan yang linear atau tidak. Dua variabel dikatakan mempunyai hubungan yang linear bila signifikansi (deviation fromLinearity) lebih dari 0,05 .

Tabel 4 Uji Linearitas

Pengujian reliabiitas selengkapnya dapat dilihat pada tabel berikut ini. Tabel 2 Uji Reabllitas

\begin{tabular}{lcl}
\hline \multicolumn{1}{c}{ Variabel } & Cronelitian & Kategori \\
\hline Stress Kerja & 0,733 & Reliabel \\
Organizational Citizenship & 0,702 & Reliabel \\
Behavior & & \\
Komitmen Organisasi & 0,738 & Reliabel \\
Kinerja Karyawan & 0,720 & Reliabel \\
\hline Sumber : Analisis Data, 2019 & &
\end{tabular}

Sumber : Analisis Data, 2019 sejauh mana suatu alat ukur dapat dipercaya atau Crobach's, dimana suatu instrumen penelitian dikatakan reliabel apabila memiliki koefisien keandalan atau alpha sebesar 0,6 atau lebih (Sugiyono, 2013).

\begin{tabular}{lcc}
\hline Hubungan Variabel Penelitian & $\begin{array}{c}\text { Deviation from } \\
\text { Linearity (Sig) }\end{array}$ & Kesimpulan \\
\hline Stress Kerja $\rightarrow$ Kinerja & 0,129 & $\begin{array}{c}\text { Linear } \\
\text { Signifikan } \\
\text { Linear } \\
\text { Signifikan } \\
\text { Linear }\end{array}$ \\
$\begin{array}{l}\text { Organizational Citizenship } \\
\text { Behavior } \rightarrow \text { Kinerja }\end{array}$ & 0,205 & $\begin{array}{c}\text { Signifikan } \\
\text { Komitmen Organisasi } \rightarrow\end{array}$ \\
Kinerja
\end{tabular}

Hasil pengujian membuktikan bahwa ketiga variabel independen memiliki hubungan yang linear dan signifikan 
terhadap variabel dependen. Hal ini dapat dilihat nilai deviation from linearity yang nilai signifikansinya semuanya berada diatas 0,05 .

c. Uji Multilinieritas

Uji Multikolenieritas bertujuan untuk menguji apakah model regresi ditemukan adanya korelasi antara variabel independen (Ghozali, 2013) Salah satu cara untukmendeteksi ada tidaknya multikolinieritas di dalam model regresi dapat dilihat dari nilai tolerance dan lawannya varian inflation factor (VIF).Apabila dalam suatu penelitian besarnya nilai VIF $\leq 10$ dan nilai tolerance $\geq 0,10$ menunjukkan tidak terdapat multikolinieritas dalam penelitian tersebut (Ghozali, 2013). Hasil uji multikolinieritas dapat dilihat pada tabel berikut ini.

Tabel 5 Uji Multikolinearitas

\begin{tabular}{lccc}
\hline \multicolumn{1}{c}{ Variabel Bebas } & $\begin{array}{c}\text { Collinearity } \\
\text { Statistics Tolerance }\end{array}$ & $\begin{array}{c}\text { Collinearity } \\
\text { Statistics VIF }\end{array}$ & Keterangan \\
\hline Stres Kerja & 0,960 & 1,042 & Non Multikol \\
Organizational & 0,563 & 1,776 & Non Multikol \\
Citizenship Behavior & 0,572 & 1,748 & Non Multikol \\
Komitmen Organisasi & & &
\end{tabular}

Berdasarkan tabel diatas dapat diketahui bahwa angka tolerance dari variabel independen semuanya menunjukkan angka $>0,10$ hal ini berarti bahwa tidak terjadi korelasi antar variabel independen. Kemudian angka variabel inflation factor (VIF) tidak ada satupun dari variabel independen yang menunjukkan angka $>10$. Dengan demikian dapat disimpulkan bahwa dalam model regresi tidak terjadi multikolinearitas antara variabel independen tersebut.

d. Uji Heteroskedastisitas

Uji heterokedastisistas bertujuan untuk menguji apakah dalam model regresi terjadi ketidaksamaan variance dari residual satu pengamatan ke pengamatan lain. Uji heterokedastisistas akan dilakukan dengan metode Uji Glejser. Duwi Priyatno (2016) menyatakan Uji Glejser yaitu meregresikan absolute residual dengan masing-masing variabel independen. Jika pada uji t nilai signifikansi antara variabel independen dengan absolute residual lebih dari 0,05 maka tidak terjadi heterokedastisitas. Adapun hasil uji heterokedastisitas dapat dilihat pada Tabel 6 berikut ini.

Tabel 6 Uji Heteroskedastisitas

\begin{tabular}{lcccc}
\hline & \multicolumn{2}{c}{$\begin{array}{c}\text { Unstandardized } \\
\text { Coefficients }\end{array}$} & $\begin{array}{c}\text { Standardize } \\
\mathrm{d} \\
\text { Model }\end{array}$ & \multicolumn{2}{c}{ Coefficients } & \multirow{2}{*}{$\mathrm{t}$} \\
\cline { 2 - 4 } & $\mathrm{B}$ & $\begin{array}{c}\text { Std. } \\
\text { Error }\end{array}$ & Beta & \\
\hline (Constant) &, 093 &, 172 & &, 540 \\
Stres_Kerja &,- 022 &, 022 &,- 032 &,- 980 \\
Organizational_Citizenz &, 186 &, 043 &, 183 & 4,268 \\
$\quad$ ship Behavior &, 801 &, 041 &, 823 & 19,387 \\
\hline Komitmen_Organisasi & & & &
\end{tabular}

Sumber : Analisis Data, 2019

Berdasarkan Hasil uji heterokedastisitas dapat dinyatakan bahwa nilai signifikansi variabel stres kerja (0,022), signifikansi variabel organizational citizenzship behavior $(0,186)$ dan signifikansi variabel komitmen organisasi $(0,801)$. Sehingga dapat disimpulkan bahwa tidak terjadi heterkodesastisitas antar variabel independen, karena nilai signifikansi masing-masing variabel telah lebih dari 0,05.

\subsection{Pengujian Hipotesis}

\section{Pengujian Hipotesis Secara Parsial (uji t)}

Model hipotesis dalam penelitian ini adalah dua arah/dua sisi, jadi untuk melakukan pengujian hipotesis peneliti akan mendapatkan t-tabel pada signifikansi 0,05 yakni Hasil pengujian hipotesis secara parsial dapat dilihat pada tabel berikut ini.

Tabel 7 Uji Hipotesis (Uji t)

\begin{tabular}{|c|c|c|c|c|c|}
\hline \multirow{2}{*}{ Model } & \multicolumn{2}{|c|}{$\begin{array}{c}\text { Unstandardized } \\
\text { Coefficients }\end{array}$} & \multirow{2}{*}{$\begin{array}{c}\begin{array}{c}\text { Standardized } \\
\text { Coefficients }\end{array} \\
\text { Beta }\end{array}$} & \multirow{2}{*}{$\mathrm{t}$} & \multirow{2}{*}{ Sig. } \\
\hline & B & $\begin{array}{c}\text { Std. } \\
\text { Error }\end{array}$ & & & \\
\hline (Constant) & ,093 &, 172 & &, 540 &, 591 \\
\hline Stress Kerja &,- 022 &, 022 &,- 032 &,- 980 &, 330 \\
\hline $\begin{array}{l}\text { Organizational } \\
\text { Citizenzship Behavior }\end{array}$ &, 186 & ,043 &, 183 & 4,268 &, 000 \\
\hline Komitmen Organisasi & ,801 & ,041 & ,823 & 19,387 & ,000 \\
\hline
\end{tabular}

Untuk mengetahui besarnya pengaruh masingmasing variabel independen stress kerja, organizational citizenship behavior, dan komitmen organisasi secara parsial terhadap variabel dependen kinerja karyawan, dapat dilakukan dengan cara melihat $\mathrm{t}$-hitung $>\mathrm{t}$-tabel $(1,664)$ dan $\alpha \leq 0,05$. Hasilnya dapat dilihat pada pengujian hipotesis dibawah ini.

a. Pengujian Hipotesis 1

Hipotesis pertama dinyatakan bahwa bahwastress kerja berpengaruh signifikan terhadap kinerja karyawan PT Japfa Comfeed Indonesia Tbk. Unit Corn Drier Sidrap. Hasil pengujian terhadap variabel stress kerja menunjukkan bahwa nilai unstandardized coefficients (B) stress kerjaterhadap kinerja sebesar -0,022 kemudian nilai t-hitung sebesar $-0,980<\mathrm{t}$-tabel 1,664dengan tingkat signifikansi sebesar 0,330 0,05 . Hasil pengujian hipotesis menunjukkan bahwa variabel stress kerja berpengaruh secara negatif dan tidak signifikan terhadap kinerja karyawan PT Japfa Comfeed Indonesia Tbk. Unit Corn Drier Sidrap. Hipotesis pertama dinyatakan dapat ditolak kebenarannya.

b. Pengujian Hipotesis 2

Hipotesis kedua dinyatakan bahwa bahwa organizational citizenship behavior berpengaruh signifikan terhadap kinerja karyawan PT Japfa Comfeed Indonesia Tbk. Unit Corn Drier Sidrap. Hasil pengujian terhadap variabel organizational citizenship behavior menunjukkan bahwa nilai unstandardized coefficients (B) organizational citizenship behavior terhadap kinerja karyawan. Sebesar 0,186 kemudian nilai t-hitung sebesar 4,268> t-tabel 1,664 dengan tingkat signifikansi sebesar $0,000<0,05$. Hasil pengujian hipotesis menunjukkan bahwa variabel organizational citizenship behavior berpengaruh positif dan signifikan terhadap kinerja karyawan PT Japfa Comfeed Indonesia Tbk. Unit Corn Drier Sidrap. Hipotesis kedua dinyatakan dapat diterima kebenarannya.

c. Pengujian Hipotesis 3 
Hipotesis ketiga dinyatakan bahwa bahwa komitmen organisasi berpengaruh positif dan signifikan terhadap kinerja karyawan PT Japfa Comfeed Indonesia Tbk. Unit Corn Drier Sidrap. Hasil pengujian terhadap variabel komitmen organisasi menunjukkan bahwa nilai unstandardized coefficients (B) komitmen organisasi terhadap kinerja sebesar 0,801 kemudian nilai t-hitung sebesar 19,387> t-tabel 1,664 dengan tingkat signifikansi sebesar $0,000<0,05$. Hasil pengujian hipotesis menunjukkan bahwa variabel komitmen organisasi berpengaruh positif dan signifikan terhadap kinerja karyawan PT Japfa Comfeed Indonesia Tbk. Unit Corn Drier Sidrap. Hipotesis ketiga dinyatakan dapat diterima kebenarannya.

2 Pengujian Hiptesis Secara Simultan (uji f)

Hipotesis keempat dinyatakan bahwa bahwa stres kerja, organizational citizenship behavior dan komitmen organisasi berpengaruh positif dan signifikan terhadap kinerja karyawan PT Japfa Comfeed Indonesia Tbk.Unit Corn Drier Sidrap.Pengujian Hipotesis ini menggunakan uji simultan $(\mathrm{F})$, dapat dilihat di tabel dibawah ini.

\section{Tabel 8 Uji Simultan (f)}

\begin{tabular}{lc|c|c|c|c}
\hline \multicolumn{1}{c}{ Model } & $\begin{array}{c}\text { Sum of } \\
\text { Squares }\end{array}$ & df & $\begin{array}{c}\text { Mean } \\
\text { Square }\end{array}$ & F & Sig. \\
\hline Regression & 5,083 & 3 & 1,694 & 297,112 &, $000^{\mathbf{b}}$ \\
\hline Residual &, 450 & 79 &, 006 & & \\
\hline Total & 5,533 & 82 & & & \\
\hline \multicolumn{2}{l}{ Sumber: Analisis Data, 2019}
\end{tabular}

Dari uji anova atau $\mathrm{F}$ test didapat nilai $\mathrm{F}$ hitung 297,112> t-tabel $(1,664)$ dengan signifikan 0,000 berada jauh lebih kecil dari 0,05 maka model regresi tersebut dapat digunakan untuk mempredisksi Stres Kerja, Organizational Citizenship Behavior dan Komitmen Organisasi secara simultan berpengaruh Kinerja Karyawan. Hasil pengujian hipotesis menunjukkan bahwa variabel Stres Kerja, Organizational Citizenship Behavior dan Komitmen Organisasi berpengaruh positif dan signifikan terhadap kinerja karyawan PT Japfa Comfeed Indonesia Tbk. Unit Corn Drier Sidrap dengan demikian hipotesis keempat dinyatakan dapat diterima kebenarannya.

\subsection{Analisis Regresi Linear Berganda}

Pengujian pengaruh stres kerja, organizatio citizenship behavior dan komitmen organisasi terhadap kinerja karyawan mengguna kan teknik analisis regresi linear berganda. Teknik ini digunakan untuk meramalkan pengaruh dua variabel atau lebih variabel bebas (X) terhadap sebuah variabel terikat (Y) atau untuk membuktikan bahwa terdapat atau tidak terdapatnya hubungan antara dua variabel atau lebih variabel bebas dengan sebuah variabel terikat. Hasil pengujian dapat dilihat pada Tabel 10 berikut ini.

Tabel 8 Hasil Analisis Regresi Linear Berganda

\begin{tabular}{|c|c|c|c|c|c|}
\hline \multirow{2}{*}{ Model } & \multicolumn{2}{|c|}{$\begin{array}{c}\text { Unstandardized } \\
\text { Coefficients }\end{array}$} & \multirow{2}{*}{$\begin{array}{c}\begin{array}{c}\text { Standardized } \\
\text { Coefficients }\end{array} \\
\text { Beta }\end{array}$} & \multirow{2}{*}{$\mathrm{t}$} & \multirow{2}{*}{ Sig. } \\
\hline & B & $\begin{array}{l}\text { Std. } \\
\text { Error }\end{array}$ & & & \\
\hline (Constant) & ,093 & ,172 & & ,540 &, 591 \\
\hline Stres_Kerja &,- 022 & 022 &,- 032 &,- 980 & 330 \\
\hline
\end{tabular}

\begin{tabular}{|lr|c|c|c|c|}
\hline $\begin{array}{l}\text { Organizational_Citize } \\
\text { nzship_Behavior }\end{array}$ &, 186 &, 043 &, 183 & 4,268 &, 000 \\
\hline Komitmen_Organisasi &, 801 &, 041 &, 823 & 19,387 &, 000 \\
\hline Sumber: Analisis Data, 2019
\end{tabular}

Berdasarkan hal tersebut maka dapat dirumuskan

persamaan regresi linear berganda sebagai berikut:

$$
Y=0,093-0,022 X 1+0,186 X 2+0,801 X 3+e
$$

Berdasarkan hasil persamaan regresi linear berganda tersebut dapat diuraikan bahwa:

1. Nilai konstanta sebesar 0,093 menyatakan bahwa jika variabel independen stres kerja, organizational citizenship behavior dan komitmen organisasi tidak ada, maka kinerja karyawan PT Japfa Comfeed Indonesia Tbk. Unit Corn Drier Sidrap hanya sebesar 0,093 satuan.

2. Nilai koefisien stres kerja sebesar $-0,022$ berarti bahwa setiap terjadi kenaikan 1 skor stres kerja, maka akan diikuti oleh penurunan kinerja karyawan PT Japfa Comfeed Indonesia Tbk. Unit Corn Drier Sidrap sebesar 0,022 satuan.

3. Nilai koefisien organizational citizenship behavior sebesar 0,186 berarti bahwa setiap terjadi kenaikan 1 skor organizational citizenship behavior karyawan, maka akan diikuti oleh kenaikan kinerja karyawan PT Japfa Comfeed Indonesia Tbk. Unit Corn Drier Sidrap sebesar 0,186 satuan.

4. Nilai koefisien komitmen organisasi sebesar 0,801berarti bahwa setiap terjadi kenaikan 1 skor komitmen organisasi karyawan, maka akan diikuti oleh kenaikan kinerja karyawan PT Japfa Comfeed Indonesia Tbk. Unit Corn Drier Sidrap sebesar 0,801 satuan.

\subsection{Pengujian Koefisien Determinasi}

Pengujian koefisien determinasi digunakan untuk menerangkan seberapa besar pengaruh dari seluruh variabel independen stres kerja, organizational citizenship behavior, dan komitmen organisasi terhadap variabel dependen kinerja karyawan PT Japfa Comfeed Indonesia Tbk. Unit Corn Drier Sidrap. Nilai Koefisien Determinasi adalah sebesar 0,919. Nilai tersebut menunjukkan bahwa pengaruh variabel independen stress kerja, organizational citizenship behavior dan komitmen organisasiterhadap variabel dependen kinerja karyawan PT Japfa Comfeed Indonesia Tbk. Unit Corn Drier Sidrap adalah sebesar 91,9\%, sedangkan sisanya 8,1\% dipengaruhi oleh variabel lain yang tidak diteliti dalam penelitian ini.

Robbins (2008) mengatakan bahwa gejala psikologikal akibat stres kerja adalah ketidakpuasan kerja yang lebih ditunjukkan dengan, kecemasan, ketegangan, kebosanan, irritabilitas dan menunda-nunda. Hasil pengujian hipotesis menunjukkan bahwa variabel stres kerja berpengaruh secara negatif dan tidak signifikan terhadap kinerja karyawan PT Japfa Comfeed Indonesia Tbk. Unit Corn Drier Sidrap. Nilai koefisien stress kerja sebesar -0,022 berarti bahwa setiap terjadi kenaikan 1 skor stres kerja, maka akan diikuti oleh penurunan 
kinerja karyawan PT Japfa Comfeed Indonesia Tbk. Unit Corn Drier Sidrap sebesar 0,022 satuan.

Jika karyawan memiliki daya tahan tinggi, maka dia akan dapat mengatasi stresnya, yang berbeda dengan orang yang daya tahannya rendah. Ketidak mampuan karyawan dalam menghadapai stres dan membiarkannya berlarut-larut berakibat pada kondisi mental dan emosional dari karyawan, yang akhirnya akan mempengaruhi kinerjanya. Sunyoto (2013) menyatakan bahwa pada tingkat stres yang rendah kinerja karyawan rendah.Pada kondisi ini karyawan tidak memiliki tantangan dan muncul kebosanan karena under simulation. Hasil penelitian ini bertentangan dengan hasil penelitian Tri Wartono (2017) ia memperoleh hasil pengaruh yang signifikan yang sangat kuat atau positif antara stres kerja terhadap kinerja karyawan yang ditunjukan dengan koefisien korelasi sebesar 0,880 dan koefisien determinasi $77,44 \%$.

Organizational Citizenship Behavior yang tertanam di dalam diri para karyawannya, yaitu perilaku kewarganegaraan organisasi sebagai perilaku individu yang secara sukarela, tidak secara langsung atau eksplisit diakui formal dengan adanya sistem penghargaan, diharapkan dapat mempromosikan keefisiensian dan keefektifan fungsi organisasi atau perilaku seseorang yang bekerja lebih dari deskripsi pekerjaan (Organ, Podsakoff, \&MacKenzie, 2006). Hasil pengujian hipotesis menunjukkan bahwa variabelorganizational citizenship behavior berpengaruh positif dan signifikan terhadap kinerja karyawan PT Japfa Comfeed Indonesia Tbk. Unit Corn Drier Sidrap. Nilai koefisien organizational citizenship behavior sebesar 0,186 berarti bahwa setiap terjadi kenaikan 1 skor organizational citizenship behavior karyawan, maka akan diikuti oleh kenaikan kinerja karyawan PT Japfa Comfeed Indonesia Tbk. Unit Corn Drier Sidrap sebesar 0,186 satuan.

Perilaku ini muncul karena perasaan sebagai anggota organisasi dan merasa puas apabila dapat melakukan sesuatu yang lebih kepada organisasi, bisa terjadi loyalitas karyawan terhadap perusahaan cukup rendah, padahal kompensasi yang diberikan perusahaan sebanding bahkan lebih dengan kontribusi yang diberikan oleh karyawan.Hal ini sesuai dengan pendapat Organ et al (2006), menyatahkan bahwa karyawan yang memiliki OCB akan memiliki loyalitas yang tinggi terhadap organisasi tempatnya bekerja, dan dengan sendirinya akan merasa nyaman dan aman terhadap pekerjaannya.

Hasil penelitian Suzana (2017) memperoleh hasil penelitian bahwa berpengaruh positif dan signifikan terhadap kinerja karyawan. Demikian juga penelitian Ticoalu (2013) bahwa Organizational Citizenship Behavior berpengaruh signifikan terhadap kinerja karyawan. Artinya karyawan yang memiliki OCB akan dapat meningkatkan kinerja karyawan, baik bagi organisasi maupun bagi diri sendiri.

Colquitt et al. (2011) bahwa komitmen organisasional adalah sebagai keinginan pada sebagian pekerja untuk tetap menjadi anggota organisasi. Hasil pengujian hipotesis menunjukkan bahwa variabel komitmen organisasi berpengaruh positif dan signifikan terhadap kinerja karyawan PT Japfa Comfeed Indonesia Tbk. Unit Corn Drier Sidrap. Nilai koefisien komitmen organisasi sebesar 0,801berarti bahwa setiap terjadi kenaikan 1 skor komitmen organisasi karyawan, maka akan diikuti oleh kenaikan kinerja karyawan PT Japfa Comfeed Indonesia Tbk. Unit Corn Drier Sidrap sebesar 0,801 satuan.

Semakin tinggi keterikatan karyawan dengan organisasi semakin baik kinerjanya dan pada gilirannya semakin baik kinerja perusahaannya. Karyawan bekerja tidak melulu untuk meraih kompensasi finansial saja namun juga nonfinansial seperti penghargaan personal dan karir karena itu tidak mungkin membangun keterikatan mereka hanya dengan pendekatan yang sangat bersifat struktural.

Hasil penelitian Damaryanthi dan Dewi (2016) memperoleh hasil komitmen organisasi berpengaruh positif dan signifikan terhadap kinerja. Artinya karyawan yang memiliki komitmen organisasiakan dapat meningkatkan kinerja karyawan, baik bagi organisasi maupun bagi diri sendiri.

Hasil pengujian hipotesis secara simultan membuktikan berpengaruh positif dan signifikan variabel Stres Kerja, Organizational Citizenship Behavior, dan Komitmen Organisasi terhadap Kinerja Karyawan. Dilihat dari nilai $F$ hitung 297,112> t-tabel $(1,664)$ dengan signifikan 0,000 berada jauh lebih kecil dari 0,05 . Hal ini menunjukkan bahwa karyawan di PT Japfa Comfeed Indonesia Tbk. Unit Corn Drier Sidrap apabila Stres Kerja terus dilakukan pencegahan atau pengurangan dampak dari stres kerja, ditunjang dengan Organizational Citizenship Behavior, dan Komitmen Organisasi yang tinggi maka akan berujung pada peningkatan Kinerja Karyawan.

Hasil pengujian koefisien determinasi adalah sebesar 0,919 . Nilai tersebut menunjukkan bahwa pengaruh variabel independen stress kerja, organizational citizenship behavior dan komitmen organisasi terhadap variabel dependen kinerja karyawan PT Japfa Comfeed Indonesia Tbk. Unit Corn Drier Sidrap adalah sebesar $91,9 \%$, sedangkan sisanya $8,1 \%$ dipengaruhi oleh variabel lain yang tidak diteliti dalam penelitian ini.

\section{SIMPULAN}

Hasil penelitian menyimpulkan bahwa stres kerja berpengarunh negatif namun tidak signifikan terhadap kinerja karyawan PT Japfa Comfeed Indonesia Tbk. Unit Corn Drier Sidrap. Organizational Citizenship Behavior (OCB) berpengaruh positif dan signifikan terhadap kinerja karyawan PT Japfa Comfeed Indonesia Tbk. Unit Corn Drier Sidrap. Komitmen Organisasi berpengaruh positif dan signifikan terhadap kinerja karyawan PT Japfa Comfeed Indonesia Tbk. Unit Corn Drier Sidrap. Sedangkan Stres Kerja, Organizational Citizenship Behavior (OCB) dan Komitmen Organisasi 
berpengaruh positif dan signifikan terhadap Kinerja Karyawan PT Japfa Comfeed Indonesia Stres Kerja, Organizational Citizenship Behavior dan Komitmen Organisasi bersama-sama dapat meningkat kinerja karyawan makanya perlu adanya perhatian dan usaha atas kemampuan dan peran karyawan dalam melaksanakan kegiatan operasional perusahaan sehingga dapat memicu kinerja karyawan yang baik untuk kemajuan organisasi.

\section{DAFTAR PUSTAKA}

Anak Agung Inten P.SD Amaryanthi dan Anak Agung Sagung Kartika Dewi (2016) Pengaruh Kecerdasan Emosional, Komitmen Organisasi, Dan Organizational Citizenship Behavior Terhadap Kinerja Pegawai Feb, E-Jurnal Manajemen Unud, Vol. 5, No. 2, 2016:790-820 ,ISSN : 2302-8912

Anna Suzana (2017) Pengaruh Organizational Citizenship Behavior (OCB) Terhadap Kinerja Karyawan (Studi Di: PT. Taspen (Persero) Kantor Cabang Cirebon), Jurnal Logika, Vol XIX No 1 April, p-ISSN : 19782560, e-ISSN : 2442-5176

Colquitt, Jason A., Jeffrey A. LePine, dan Michael J. Wesson. (2011). Organizational Behavior: Improving Performance and Commitment in the Workplace. Edisi 2. New York: Mc-Graw Hill/Irwin.

Ghozali, I. (2013). Aplikasi Analisis Multivariate dengan Program IBM SPSS 21. Semarang: Universitas Diponegoro.

Linda Kartini Ticoalu (2013) Organizational Citizenship Behavior (OCB) Dan Komitmen Organisasi Pengaruhnya Terhadap Kinerja Karyawan, Jurnal EMBA Vol. 1 No. 4 Desember 2013, Hal. 782-790

Luthans, Fred. (2006). Organizational Behavior, 7th edition. New York: Mc. Graw Hill Book Compan

Mangkunegara, A. A. Anwar Prabu. 2013. Manajemen Sumber Daya Manusia. Jakarta: Rineka Cipta

Pigome, hoseo, Sapiri, M., \& Abduh, T. 2019. Pengaruh Kecerdasan Emosional, Komitmen Organisasi Dan Organizational Citizenship Behavior Terhadap Kinerja Perawat Rumah Sakit Umum Daerah Kabupaten Paniai Propinsi Papua. Indonesian Journal of Business and Management, 1(2), 48-58.

Robbins, Stephens P. dan Timothy A. Judge. (2008). Perilaku Organisasi. Edisi Indonesia Jilid 1. Jakarta: Salemba Empat.

Sugiyono. (2015). Metode Penelitian Kuantitatif Kualitatif dan R\&D. Bandung: Alfabeta.

Tri Wartono (2017) Pengaruh Stres Kerja Terhadap Kinerja Karyawan (Studi Pada Karyawan Majalah Mother And Baby), Jurnal Ilmiah Prodi Manajemen Universitas Pamulang | Vol. 4, No.2, April

Martiyani Pristiwati dan Sunuharyo Swasto Bambang (2018), Pengaruh Komitmen Organisasional Dan Organizational Citizenship Behavior Terhadap Kinerja Karyawan (Studi Pada Karyawan PT PLN (Persero) Area Sidoarjo), Jurnal Administrasi Bisnis (JAB)|Vol. 61 No. 4 Agustus 2018 